Journal of Social and Development Sciences (ISSN 2221-1152)

Vol. 7, No. 3, pp. 11-19, September 2016

\title{
The Thick Black and White Ocean among Buddhist Pilgrimage Tourist Operators in Thailand
}

\author{
Kittichok Nithisathian ${ }^{* 1}$, Lavanchawee Sujarittanonta², John C. Walsh ${ }^{1}$ \\ ${ }^{1}$ Graduate School, Stamford University, Thailand \\ ${ }^{2}$ School of Management, Shinawatra University, Thailand \\ ${ }^{3}$ I-Shou University, Taiwan \\ *kittichok.n@gmail.com, lavanchawee@hotmail.com, jcwalsh100@hotmail.com
}

\begin{abstract}
The White Ocean strategy proposed by Thai scholar Danai Chanchaochai addresses management based on Buddhist philosophy, and emphasizes the society first before looking to oneself. At the same time, there is also the concept of Black Ocean, or Hòuhēixué (厚黑學) which translates to Thick Black Theory, proposed by Li Zongwu (李宗吾). Theoretically, an understanding of both white and black can lead the businessman to adjust his plans for better performance. Therefore, this research examines both Black and White concepts in the context of religious tourism, by collecting business data from tour operators that offer pilgrimage packages to Buddhists. It was found that the Buddhist aspect of the religious tour businesses puts "Blackness" profiteering goals in the background by building a "White" image of charity and donations, thus suggesting that the Black and White co-exists and are inseparable, similar to the middle path or yin-yang balance in nature.
\end{abstract}

Keywords: White Ocean Strategy, Black Ocean Strategy, religious tour operators

\section{Introduction}

The development of strategy literature in the West continues in the East. The well-known Blue Ocean strategy (BOS) developed at INSEAD, France, by Professors W. Chan Kim and Renée Mauborgne(Kim \& Mauborgne, 2005)have struck a chord in the Asian holistic mindset, resulting in further development of colors along the yin-yang concept, into Black and White Ocean theories. In particular, this paper examines the applicability of the Black and White Ocean theories on East Asian business management practice - tourism by East Asians (Chinese) in South East Asian host country (Thailand). Chinese tourist spends almost 1.2 trillion yuan (around USD 183 billion) and bought 46 percent of all luxury goods sold globally in the year 2015 (Jing Daily, 2016). There is no doubt about Chinese tourist purchasing power, however the way tourist company treats Chinese tourist is still questionable. "Forced shopping tour" is common tours through China and for Chinese tourist globally. The inexpensive tour price has been set to attract tourist to join the program by expecting them to spend money on designated shopping places like a jewelry place. However, many people in the tour group may not want to shop for most of the product is overpriced. In that case, the tour guide will come and encourage them to purchase more. In October 2015, a Chinese tourist has died in Hong Kong a day after being beaten up by tour leader who forced him to purchase at a souvenir shop (BBC, 2015). The "force shopping tour" is another kind of business model that trap customer with supercheap product followed by unfair treatment.

In the risk - return spectrum the more return sought, the more risk that must be undertaken. In short, we may have called "High Risk, High Return". Literature has suggested several strategies to reduce the risk and increase the return. Strategic literature has suggested using vision to utilize resources and capabilities to win the competitors while Kim and Renee suggested "Blue Ocean Strategy" which focused on the new marketing frontier as another way to increase the return. The "force shopping tour" does not consider Blue Ocean Strategy, in the other hand it must be considered as super "Red Ocean Strategy" where all the player in the market try to compete aggressively in the existing market space. On the other perspective of strategy, the researcher is focused more on the moral level of the company. Just a few years after the blue ocean strategy has been published, Danai has explained in his book "White Ocean Strategy" that it is better to return to the society first before return to yourself. This is related to corporate social responsibility (CSR) and the recent work of Kotler "Marketing 3.0" that suggested that consumer is moving toward the human spirit rather than a 
product benefit or consumer advantages (Kotler, Kartajaya, \& Setiawan, 2010). The "force shopping tour" is considered a low level of moral or in short very poor in White Ocean Strategy, and very strong in Black Ocean Strategy. So what is Black Ocean Strategy?

\section{Literature Review}

Conceptualizing Black Ocean Strategy: The blue ocean strategy, first promoted in the Harvard Business Review of October 2004 (Kim \& Mauborgne, Blue Ocean Strategy, 2005), has had better days. "Blue Ocean" refers to untapped markets, which provide little competition for anyone diving in. The phrase "Red Ocean", on the other hand, refers to a saturated market. Most oceans today, unfortunately for investors, remain as red as a red carpet; and business scholars in desperate need for a concept that better encompasses innovation and creates more value for future markets. We want to put an end, in this paper, to this anxiety by giving the black ocean strategy a long awaited twist: simply stated, any product you make, any decision you take, any employee you forsake ("every breath you take", as Sting would have it) must be seen somehow in black. Our revolutionary proposition is rooted in three main influences, although we are more daring in our approach and thus reach far beyond their conclusions.

The first is Murnighan's (2012) Do Nothing! thesis that tells leaders to stop worrying and start thinking. Too many managers fail to acknowledge that thinking is a form of doing. Instead, they interfere with everyone and everything and deteriorate their own organization's performance. What facilitates navigation in turbulent waters? How can successful companies sneak their ways through aggressively competitive markets? It is certainly not a nervous captain aboard an old ship that will fight the strongest winds and overcome the highest waves. The opposite is true: the captain himself should be old and serene (by "old", we mean experienced) while maintaining the ship so that it endures the test of time and reemerges constantly victorious out of the roughest tempests. The ship never gets old (the company always innovates) and the captain only gets wiser from his challenges (the leader supervises others, but no longer handles the tools himself). The notion of maintenance was discussed in Zen and the Art of Motorcycle Maintenance (Pirsing, 1974), a silly classic in our opinion, but which at least asks the questions management science is most concerned with: in what conditions should I leave to others what I might be able to do myself? Murnighan's(2012)is fair enough -trust others and don't do anything that could compromise this trust. In this respect, his account and others such as Who Moved My Cheese? (Johnson, 1998) are much more convincing than the motorcyclesque, hippie-go-lucky, road-movie pedantry cited above. If as a manager you try too hard and too often, if you are too present, then you will struggle inefficiently on a cruise-ship with staff that is reluctant to work, complaining customers and the gigantic waves of competition looming all around. Such is the "blue ocean strategy" that works in the short term, whereas the markets are bound to turn red in the long term, threatening to drown you, along with your team who already lost any hope of satisfying irritated tourists. If on the contrary you decide to do nothing, then you will sit confidently on a rowing boat at night, gently trailing the dark, peaceful waters, and watching faithful employees guide your company amidst the relaxing drones of innocuous dragonflies. This latter "Black Ocean Strategy" is how we picture it: a rowingboat rather than a cruise-ship; a lake at night rather than a daytime ocean; a sizeable team rather than strangers left to themselves and "managed" by an angry captain who knows nothing about them. The Black Ocean Strategy is this romantic lake under the moonlight.

The second influence originates from the history of the black color, which consolidates the argument that stubbornness pays off, that great leaders actually disengage themselves from their own business, that they take instinctive decisions without studying the market, without even trying to understand what would make customers happy (customers themselves do not know what they want). In business, black became more prevalent from the Protestant Reformation's aversion to vivid colors. By the sixteenth century, red, yellow, and green were considered immodest -as opposed to the more dignified black-gray-white axis. Such values still held sway in the second half of the nineteenth century with the Industrial Revolution in Europe and the rise of mass consumption in America. Most products fell within a narrow chromatic range where white, black, gray, and brown dominated. This was one of the enduring effects of the Protestant ethic (which Weber famously associated to the development of capitalism). Thus, even though it was technically possible to produce any color, the first telephones, cameras, pens, cars and clothes fell within the range of white to black between 1860 and 1920. The most notorious example of this black-and-white focus was that of Henry Ford. 
Despite public expectations, despite the two-tone and three-tone vehicles offered by his competitors, despite the growing place for colors in daily life, he refused for moral reasons to sell any but black cars up until the end of his life. The famous Model T produced from 1908 to 1927, the company's trademark, epitomizes this rejection of color (Pastoureau, 2008, p. 76). In this way, gSreat leaders simply happen to do what they want, independently of internal gossips and external public opinion. The Black Ocean Strategy consists in other words in taking wild guesses in the dark.

Lastly, the most powerful influence for us has been Aithal and Suresh Kumar's (2015)discussion of the Black Ocean Strategy, which begins with an incisive, life-changing observation on the way most businesses should operate. At the time of writing, top-level executive managers, corporate masters, management gurus and Nobel-Prize thinkers choose from a variety of colors that boost organizational development and sustainability. The red ocean strategy, the blue ocean strategy, the green ocean strategy and the purple ocean strategy all bring undeniable benefits to strategic decision making, intelligent management, and monitoring of competition. However, developing countries must overcome their problems and find quick, short-term relief. Loose strategic planning is always akin, to the best of our knowledge (and as business scholars we are extremely knowledgeable), to some sort of business diarrhea. It takes a lot of capital to feed the monster -say, a multinational company -but in the end it is painfully digested and leaves an embarrassing smell fouling the air even after everything has been flushed down. To avoid facing the ignominy of business disaster and subsequently losing face, trust us: only the black ocean strategy is worth following. Indeed, the most successful firms opt for the black ocean strategy nowadays, because it offers flawless decisions for sustainability through an easily applicable investment-perceived risk matrix. In another groundbreaking piece of work, Aithal, Shailashree and Suresh Kumar (2015) analyze features of the black ocean strategy using the superb ABCD technique. This technique impeccably identifies advantages, benefits, constraints, and disadvantages under various organizational circumstances. They clearly demonstrate that the ABCD technique should become the norm in business science, since it allows managers to evaluate any system and any concept. Combined to the relevant frameworks, the Black Ocean Strategy is this unbeatable plan for the company's prosperous future.

Corporate Social Responsibility: The goal of corporate social responsibility (CSR) is to encourage a positive impact through its activities on the environment, consumers, employees, communities, future generations, shareholders and other stakeholders. It concerns a corporate's strategy, operations, and governance structure that creates environmental and social values by monitoring and ensuring compliance with the spirit of the law, ethical standards, and international norms. In short, CSR means doing good, but it goes by many names, including social responsibility, corporate social responsibility, corporate citizenship, corporate philanthropy, corporate giving, corporate community involvement, community relations, community affairs, community development, corporate responsibility, global citizenship, and corporate societal marketing (Kotler \& Lee, 2005). CSR has been first discussing in 1950s by Howard Bowen, still numerous modern literature still discusses about CSR. Cheng et al. (2015) has summarize the positive impact of CSR as providing better access to valuable resources (Cochran \& Wood, 1984; Waddock \& Graves, 1997), attracting and retaining higher quality employees (Turban \& Greening, 1997; Greening \& Turban, 2000), allowing for better marketing of products and services (Moskowitz, 1972; Fombrun, 1996), and creating unforeseen opportunities (Frombrun, et al., 2000). The recent research showing that CSR resulted in higher stock returns sensitivity to earnings surprises and higher trading volumes for firms with higher CSR activities (Bartov \& Yan, 2015).

Literature also argues about benefit of CSR. Visser has argued that CSR has failed as a business governance and ethics system (Visser, 2010). We could not denial that primary institution in today society, overshadowing the state in controlling the direction of individual lives and influencing social development. Sad but true they have been frequently accused of being irresponsible or ignorant against the growing societal and environmental problems (Deetz, 1992). According to Carroll most obvious corporate social responsibility for corporate is economic responsibility where corporate must be focus on profit (Carroll, 1996). Literature also argues that corporate may not enjoy the CSR competitive advantages if they do not a proper CSR communication instrument (Vytautas \& Vytautas, 2008). In fact, most company perceive CSR as another public relations and marketing tools to build up corporate image, goodwill, insulating the firm from the negative impacts rather than being nice to society (Anticsr.com, 2015; Janssen, et al., 2015). Also the awareness of CSR toward customers and employees is considered low. The current research showing that 
less than half of consumer knows the meaning of the term CSR and only $11 \%$ say they have heard communication about CSR from any company in the past year. Also only $22 \%$ of employees are aware that their companies have CSR practices. (Penn Schoen Berland ,2010)

Black Ocean Strategy: Danai has suggested that instead of looking through the competition, corporate better offer a new moral attitude, an attitude of responsibility not only to employees but towards humanity and the environment. It is about time for a change. It is the passion for corporate to balance the important of people, planet, and profit. He proposed that underneath the Blue and Red Ocean lies the pure White Ocean for sustainable business development (Chanchaochai, 2009). Black Ocean Strategy follows the work of Li Zongwu (李宗吾) (1879-1943) the writer of Think Black theory (厚黑學) and found that the last Ocean strategy is Black Ocean which is the opposite vertical of White Ocean. The theory is original written by Chinese scholar name Li Zong Wu (李宗吾: Li ZōngWú) in the year 1911. Chin Ning Chu the president of Asian Marketing Consultants, Inc., international lecturer, corporate trainer, consultant, and author of Thick Face Black Heart has explained that Thick Black theory describes the secret law of nature that governs successful behaviour in every aspect of life (Chu, 1992). It is the nature's truth and about developing the outlook on life to succeed. The core discussion of Thick Black theory is how to improve effectiveness of people (Zhao, 2011) rather than being cruel. Thick Black theory is the wisdom that can be applied to any nationality, race, and occupation. It is how to protect yourself from dealing with society and in turn it is the instrument to battle with society. Thick Black discusses how to gain power (Zhao, 2011). The power of Thick Black theory is in your inner strength and the natural state of your true self, where perfect joy, clarity, courage, and compassion, are an inseparable part of you (Chu, 1992).

Thick Black theory discusses how to identify what is your main objective of your true self, and how to achieve your main goal without obstruction by social moral and condition (Chu, 1992). It is not destiny but a series of decision making (Zhao, 2011). The more practice of Thick Black theory will increase the skill, as well as improve the benefit gained by the Thick Black theory. In the big picture, Thick Black theory discusses about the ability to conceal the actual sentiment in order to shape the attitude of opponents to the way the executer wishes for, and the ability to make the right choice devoid of apprehension to other injury (Suwannakitti, 2007). According to the name of Thick Black Theory (厚黑学: Hòuhēixué) there are two main elements to it, which is "Thick" (厚) or “Thick Face", and "Black" (黑) or "Black Heart". Li Zong Wu said, "When you conceal your will from others, that is "Thick" and when you impose your will on others that is "Black". Booth Thick and Black is the human weapon to deal with the social moral and condition. Thick is a shield to protect and Black is the spear to battle (Li, 2009). Thick or thick face is a shield with the ability to protect oneself from the criticism and the negative opinions of others. It is the ability to put self-doubt aside, and refusing to accept the limitations that others have tried to impose, and the ability to carry on to achieve the target or goal (Chu, 1992). Black or Black Heart is a spear with the ability to do battle with others and one regard to how the consequences will affect others. It is cruel but not necessarily evil (Chu, 1992). The Black Heart person is above short sighted compassion. He focuses his attention on his goals and ignores the cost.

Trust: Trust, n.: In American politics, a large corporation composed in greater part of thrifty working men, widows of small means, orphans in the care of guardians and the courts, with many similar malefactors and public enemies. Ambrose Bierce, The Devil's Dictionary (Bierce, 1993). Trust is one of the most frequently examined in today's literature (Bunker, Alban \& Lewicki, 2004). It is considered to be the central feature of a business alliance (Mohr \& Speakman, 1994). It is wisdom that can influence people to do things according to organization interests. It is the glue that holds everything together, creates healthy communities and successful businesses (Schwab \& Malleret, 2003). Stephen M. R. Covey son of Stephen Covey, author of the "7 Habits" books mentioned that trust could help reduce cost and increase the speed of outcome (Stephen \& Merrill, 2006). He concludes that trust can build or destroy every human relationship. In international level, it can amplify economic growth (Knack \& Keefer, 1997; La Porta, Lopez-de-Silanes, Shleifer \&Vishny, 1997; Zak \& Knack, 2001), in micro level it is the key success factory of business alliance (Kanter, 1994). It can increase supply chain performance (Zaheer, McEvily \& Perrone, 1998; Sako, 2000; Dyer \& Chu, 2003), reduce cost, increase the speed of outcome (Dyer \& Chu, 2003; Stephen \& Merrill, 2006) and has a positive on just in time and continuous improvement process of the firm (Sako, 2000). 
In term of inter organizational trust is collectively held trust orientation toward the partner firm (Serva, Fuller, \& Mayer, 2005; Zaheer, McEvily, \&Perrone, 1998). It is a very complex construct, with multiple levels, different bases, and determinants (Rousseau, Stikin, Burt \& Camerer, 1998). Trust is also considered a key factor in effective supply chain management and, while it does not lend itself easily to measurement, the value of trust can be measured in terms of lower costs, added value and the encouragement of resource sharing (Landry, 1998). Anderson and Narus (1990) suggest that once trust is established, organizations learn that joint efforts will lead to outcomes that exceed what the organization would achieve had they acted solely in its own best interests. Additionally, business alliances that exhibit trust will survive greater stress, display greater adaptability, and survive for longer periods of time. Finally, Barney and Hansen (1994) supported that business alliances characterized by strong-form trustworthiness may have a competitive advantage over other business alliances due to the potential to decrease governance and agency costs. Trust has been challenged by other academics such as literature suggested that easy to trust manner cause opportunistic risk and unable to protect strategic resources (Zand, 1972; Mayer, Davis \& Schoorman, 1995; Williams, 2001; Bönte, 2008). The higher the social class the less significant in easy to trust behaviour (Piff, Kraus, Côté, Cheng, \& Keltner, 2010). In addition, deliberate cheats commonly use trust as a tool to deceive, while opportunistic partners take advantage when they become trusted (Nithisathian, Rattanakomut, \& Walsh, Empirical investigation of the proficiency of selecting partners in the Thai fine gold jewellery industry, 2011). The trust trap created by deliberate cheat and opportunistic is very hazardous since it can create a false memory, which has a long term effect (Zhu, Chen, Loftus, Lin \& Dong, 2010).

\section{Methodology}

This paper is using empirical study as a main tool which includes literature survey and industrial survey and some current statistics. Nonetheless, there might have some limitations incurring from the industrial survey due to time and number of respondents.

Black Ocean Strategy Concept: Black Ocean strategy discuss about the ability to pay the firm first before paying other which is totally opposite from White Ocean strategy. It works directly with opportunity. The organization must know where the opportunity is and try to find the way to access to that opportunity as well as try to find the way to block other competitors to penetrate the same opportunity. Black Ocean strategy is deal directly with trust where literatures both qualitative and quantitative research revealed a significant of trust as the wisdom to influence people to do things according to organization interests.

Black Ocean Strategy operates in 2 parts:

- Ways to create opportunities

- Ways to maintain and obtain benefits from opportunities

Ways to create opportunities: First of all, the company has to envisage business opportunities that are interesting for the company, whereby Black Ocean is different from White Ocean in that White Ocean puts social benefits first, while Black Ocean puts the company's benefits first. Therefore, the motives in finding opportunities are concerned with the company as the main priority, not with impact to people nor society. Following that, the company then seeks ways to obtain opportunities, which might be general means, or other means, such as bribery (reward), making competitors/customers feel that they would lose out if they do not cooperate with the company (punishment), and strives to side with the side that would help to realize the opportunities, regardless of whether that action is right or immoral. Ways to maintain and obtain benefits from opportunities: Secondly, the company will use psychological /emotional contract as well as documented contracts, in order to secure the company's ownership of that opportunity in the long term. At the same time, the company will try to make the most of the opportunities as much as possible.

Black Ocean Strategy the case of multi-level marketing Buddhist pilgrimage tourist operators: Buddhist pilgrimage tourist is a great opportunity business. It has the potential to attract the large Buddhist population in Thailand and from nearby Asian countries. It also creates developing local supply chains and income generating opportunities through tourism. However, business tourist operators find an opportunity to make more money from this business. Recently Chinese tourist operators start to make contract, or concession with temple in Phuket to manage the property inside the temple (นนทฤทธิ์, 2016). We can analyze the operational methods of Chinese tour companies according to the Black Ocean Strategy as follows: 
Ways to create opportunities: Chinese tour operators look for temples that are suitable for tourism, and offer several benefits for the temples, such as offering concrete floor for parking lots, renovating the toilets, building garbage storage facilities, and paying utility bills (water and electricity) for the temple, including building a shrine of the four-faced Buddha at the front entrance of the temple for free, which is popularly worshiped by Chinese tourists. (In fact, it is about landscape improvement so that Chinese tourists would want to visit more, i.e. bringing more benefits back to the Chinese tour operators.) In all, what this research is points out is that in order to create business opportunities, Chinese tour operators aim to rent Buddhist shrine and sanctuaries and turn them into tourist destinations that Chinese tourists have to come and worship as much as possible. This goes against Thai people's social norms, as temples are viewed as national treasures, but it has inadvertently resulted in ways for foreigners (Chinese businesses) to come and reap benefits from.

Ways to maintain and obtain benefits from opportunities: When the Chinese tour operator is able to make use of the abbot's sanctuary, they sign a 3 year concession contract, in order to prevent others from intervening in the benefits of the Chinese tours. This closes the opportunity for other competitors, and from then on, the Chinese tour operators can also start selling the Buddhist amulets of the temple. The cost price of each amulet is unlikely to exceed 10 baht each, but can be priced at 500-1000 baht, making a profit of 50 to 100 times. With the buying power of the huge mass of tourists who desire these amulets, this can be considered a highly successful business.

\section{Analysis and Discussion}

Black Ocean Strategy is another effective tool for organization. If organization knows how to use Black Ocean Strategy, it will create a good opportunity for organisation. Organization can enjoy large profit from monopoly existing market which is much better than uncontested market space. However, Black Ocean Strategy may not be the ethical tool for public. It may seem to be cruel and create bad effect to other people. For temple or firm that has been treated by Black Ocean strategy it is better to study the real attention of their partner. It is better to have cautious relationship with other (Nithisathian, et al., 2012).

\section{Conclusion}

Black Ocean strategy is another strategy that organization has been applied for long. It may be the first strategy that organization has been used. It talking about pay the organization first before paying other. It does not mean ruthless but it is how to make organization best use its resource to pay itself. Black Ocean strategy can be both ethical and unethical activities. It is about the ability to execute all the activities to make organization success as well as the ability to manage the attitude of publicity. For example, attitude of employee toward implementing the strategy, customers toward accepting the strategy, and public audience toward appreciate the strategy. The key activities of Black Ocean strategy are not ending up at winning the opportunity, but also how to lock the opportunity and avoid other competitors to get into organization frontier. Since Black Ocean strategy can be both ethical and unethical. It has been suggested that firm must be caution to the activities of another firm. Since trust will lose their guard which in turn effect the performance at the end. This research looked at the Black Ocean strategy in practice that of tourism by East Asians (Chinese) in South East Asian host country (Thailand).

However, the applicability of the Black Ocean needs to be studied in several other contexts, not only in Asia but also in the West, not only service industries but also in production industries. It is likely that the manifestation of Black Ocean strategy would be influenced strongly by socio-cultural environment. Future comparative and cross-cultural research can help to enrich the Black Ocean strategy, and shed further insights, such as comparing the likelihood and the time span of success, depending on the intensity of blackness (or whiteness) of this theory. Surely, there are also cases of failures in the Black Ocean strategy, given that the value behind this theory is that of immorality and evilness. Furthermore, a longitudinal study of the Black Ocean strategy in operation might likely produce interesting findings. Would the Black Ocean eventually develop into gradations of Grey, or even White Ocean or Blue Ocean? Given the concept of sustainability, what could be the other social and market forces that would come into play to exert influences on unconscionable business practices? By nature, the invisible hand would act to create equilibrium, bringing 
about more fairness as time passes. Truly, the relatively new theory of Black Ocean strategy still needs to be tested rigorously.

\section{References}

Aithal, P. S. \& Suresh Kumar, P. M. (2015). Black Ocean Strategy: A Probe into a New Type of Strategy Used for Organizational success. International Journal of Management Research, 3(8), 45-65.

Aithal, P. S., Shailashree, V. T. \& Suresh Kumar, P. M. (2015). Application of ABCD Analysis Model for Black Ocean Strategy. International Journal of Applied Research, 1(10), 331-337.

Anderson, J. \& Narus, J. (1990). A model of distributor firm and manufacturer firm working relationships. Journal of Marketing, 54, 42-58.

Anticsr.com. (2015, May 17). Anti Corporate Social Resonsibility. Retrieved May 10, 2015, from http://anticsr.com/

Barney, J. \& Hansen, M. A. (1994). Trustworthiness as a source of competitive advantage. Strategic Management Journal, 15, 175-190.

Bartov, E. \& Yan, L. (2015). Corporate Social Responsibility and the Market Pricing of Corporate Earnings. Hobart, Australia: Accounting \& Finance Association of Australia and New Zealand.

BBC. (2015, October 20). Hong Kong 'forced shopping' attack sees tourist killed. Retrieved from BBC: http://www.bbc.com/news/world-asia-34584235

Bierce, A. (1993). The Devil's Dictionary - Ambrose Bierce. (D. Thrift, Ed.) Mineola, NY: Dover.

Bunker, B. B., Alban, B. T. \& Lewicki, R. J. (2004). Ideas in currency and OD practice: has the well gone dry? Journal of Applied Behavioral, 40, 403-422.

Bönte, W. (2008). Inter-firm trust in buyer-supplier relations: Are knowledge spillovers and geographical proximity relevant? Journal of Economic Behavior \& Organization, 67, 855-870.

Carroll, M. (1996). Counselling Supervision: Theory, Skills and Practice. London: Cassell.

Chanchaochai, D. (2009). White Ocean Strategy . Bangkok: DMG books.

Cheng, B., Ioannis, I. \& George, S. (2015). Corporate Social Responsiblity and Access to Finance. Strategic Management Journal, 35(1), 1-23.

Chirinos, W. (2006). 10 Key Benefits Why MLM Programs Are Great Businesses. Retrieved August 8, 2015, from http://www.articlesfactory.com/articles/mlm/10-key-benefits-why-mlm-programs-are-greatbusinesses.html

Chu, C. N. (1992). Thick face black heart. Beavertown, OR: AMC Publishing.

Cochran, P. L. \& Wood, R. A. (1984). Corporate social responsibility and financial performance. Academy of Management journal, 27, 42-56.

Deetz, S. (1992). Democracy in an age of corporate colonization: Developments in communication and the politics of everyday life. New York: State University of New York Press.

Dyer, J. H. \& Chu, W. (2003). The role of trustworthiness in reducing transaction costs and improving performance: empirical evidence from the United States, Japan and Korea. Organization Science, 14, 57-68.

FitzPatrick, R. L. (2004). The Myth of "Income Opportunity" in Multi-Level Marketing. Charlotte, NC USA: Pyramid Scheme Alert.

Fombrun, C. J. (1996). Reputation: Realizing value from the corporate image. Boston, MA: Harvard Business School Press.

Frombrun, C. J., Gardberg, N. A. \& Barnett, M. L. (2000). Opportunity platforms and safety nets: Corporate citizenship and reputational risk. Business and Society Review, 105(1), 85-106.

Greening, D. W. \& Turban, D. B. (2000). Corporate social performance as a competitive advantage in attracting a quality workforce. Business \& Society, 39(3), 254-280.

Hicken, M. (2013). The money behind Herbalife, Mary Kay and others. Retrieved August 5, 2015, from http://money.cnn.com/2013/01/09/pf/multilevel-marketing-industry/

Janssen, C., Sen, S. \& Bhattacharya, C. B. (2015). Corporate crises in the age of corporate social responsibility. Business Horizons, 58(2), 183-192.

Jing Daily. (2016, February 16). Report: Chinese Shoppers Bought Almost Half the World's Luxury Goods in 2015. Retrieved from Jing Daily: https://jingdaily.com/report-chinese-shoppers-bought-almost-halfthe-worlds-luxury-goods-in-2015/ 
Johnson, S. (1998). Who Moved my Cheese? London: Putnam.

Kanter, R. M. (1994). Collaborative advantage: the art of alliances. Harvard Business Review, 2, 96-108.

Kim, W. C. \& Mauborgne, R. (2005). Blue Ocean Strategy. Harvard Business School Press.

Kim, W. C. \& Mauborgne, R. (2005). Blue ocean strategy: from the theory to practice. California Management Review, 47(3), 105-121.

Knack, S. \& Keefer, P. (1997). Does social capital have an economic payoff? a cross-country investigation. Quarterly Journal of Economics, 112, 1251-1288.

Kotler, P. \& Lee, N. (2005). Corporate Social Responsibility: Doing the Most Good for Your Company and Your Cause. Hoboken, NJ: John Wiley \& Sons, Inc.

Kotler, P., Kartajaya, H. \& Setiawan, I. (2010). Marketing 3.0: From Products to Customers to the Human Spirit. Hoboken, N.J.: Wiley.

La Porta, R., Lopez-de-Silanes, F., Shleifer, A. \& Vishny, R. (1997). Trust in large organizations. American Economic Review, 87, 333-338.

Landry, J. T. (1998). The value of trust. Harvard Business Review, 76(1), 18-19.

Li, Z. W. (2009). Thick black theory: Forbideen strategies for victory. (A. X. Zhao, Trans.) USA: CreateSpace.

Mayer, R. C., Davis, J. H. \& Schoorman, F. D. (1995). An integrative model of organization trust. Academy of Management Review, 20, 709-734.

Mohr, J. \& Speakman, R. (1994). Characteristics of partnership success: partnership attributes, communication, behavior and conflict resolution techniques. Strategic Management Journal, 15, 135152.

Moskowitz, M. (1972). Choosing socially responsible stocks. Business and Society Review, 1(1), 71-75.

Murnighan, J. K. (2012). Do Nothing! How to Stop Over managing and Become a great Leader. London: Portfolio.

Nithisathian, K., Rattanakomut, S. \& Walsh, J. (2011). Empirical investigation of the proficiency of selecting partners in the Thai fine gold jewellery industry. World business economics and finance conference. Bangkok: World Business Institude, Australia.

Nithisathian, K., Rattanakomut, S. \& Walsh, J. (2012). Empirical Investigation of Partnership Selection Proficiency in Thai Fine Gold Jewellery Industry. World Journal of Social Sciences, 2(2), 61-73.

Pastoureau, M. (2008). Noir: Histoire d'une couleur. Paris: Seuil.

Penn Schoen Berland. (2010). Corporate Social Responsibility Branding Survey. New York: Penn Schoen Berland.

Piff, P. K., Kraus, M. W., Côté, S., Cheng, B. \& Keltner, D. (2010). Having less, giving more: The influence of social class on prosocial behavior. Journal of Personality and Social Psychology, 99(5), 771-784.

Pirsing, R. M. (1974). Zen and the Art of Motorcycle Maintenance. New York: William Morrow \& Company.

Rousseau, D. M., Stikin, S. B., Burt, R. S. \& Camerer, C. (1998). Not so different after all: a cross-discipline view of trust. Academic Management Review, 23(3), 393-404.

Sako, M. (2000). Does trust improve business performance? In C. Lane, \& R. Backmann, Trust Within and Between Organizations (pp. 88-117). Oxford: Oxford University Press.

Schwab, K. \& Malleret, T. (2003). The trust deficit. The Wall Street Journal, 2, A10.

Serva, M. A., Fuller, M. A. \& Mayer, R. C. (2005). The reciprocal nature of trust: a longitudinal study of interacting teams. Journal of Organizational Behavior, 26, 625-648.

Stephen, M. R. \& Merrill, R. R. (2006). The speed of trust: The one thing that change everything. New York, New York: Free Press.

Suwannakitti, P. (2007). สูตรลับเศรษ [ [Millionaire Code]. Bangkok : Organic Book.

Turban, D. B. \& Greening, D. W. (1997). Corporate social performance and organizational attractiveness to prospective employees. The Academy of Management Journal, 40(3), 658-672.

Visser, W. (2010). The age of responsibility: CSR 2.0 and the New DNA of business. Journal of business systems, governance and ethics, 5(3), 7.

Vytautas, J. \& Vytautas, S. (2008). Influence of Corporate Social Responsibilit. Engineering economics, 58(3).

Waddock, S. A. \& Graves, S. B. (1997). The corporate social performance-financial performance link. Strategic Management Journal, 18(4), 303-319.

Williams, M. (2001). In whom we trust: group membership as an affective context for trust development. Academy of Management Review, 26(3), 377-396.

Zaheer, A., McEvily, B. \& Perrone, V. (1998). Does trust matter? Exploring the effects of interorganizational and interpersonal trust on performance. Organization Science, 9, 141-159. 
Zak, P. J. \& Knack, S. (2001). Trust and growth. Economic Journal, 111, 295-321.

Zand, D. E. (1972). Trust and managerial proflbem solving. Administrative Science Quarterly, 17, 229-239.

Zhao, X. A. (2011, Jan 03). Understanding Thick Black Theory. Retrieved July 08, 2012, from youtube: http://www.youtube.com/watch?v=p2t-LmXTIBo

Zhu, B., Chen, C. F., Loftus, E., Lin, C. \& Dong, Q. (2010). Treat and trick: A new way to increase false memory. Applied Cognitive Psychology, 24(9), 1199-1208.

นนทฤทธิ์, (2016, July

$10)$.

ทุนจีนรุกเซ้งวัดดัง ลุยกินรวบพุทธพาณิชย์.... อ่านต่อ ได้ที่ :

http://www.posttoday.com/social/think/431088.

Retrieved

from

Post

Today: http://www.posttoday.com/social/think/431088. 